\title{
REPUBLIC 382A-D: \\ ON THE DANGERS AND BENEFITS OF FALSEHOOD
}

\author{
NICHOLAS R. BAIMA
}

\section{INTRODUCTION}

$\gamma^{2}$

OCRATES' ATTITUDE TOWARD falsehood in the Republic is quite puzzling. ${ }^{1}$ Although Socrates is clearly committed to truth, at several points he discusses the benefits of falsehood. This occurs most notably in Book 3 with the "noble lie" (414d-415c) and most disturbingly in Book 5 with the "rigged sexual lottery" (459d-460c). This raises the question: What kinds of falsehoods does Socrates think are beneficial, and what kinds of falsehoods does he think are harmful? And more broadly: What can this tell us about the relationship between ethics and epistemology?

The key to answering these questions lies in an obscure and paradoxical passage in Book 2.382a-d, when Socrates distinguishes between "true falsehoods" and "impure lies." True falsehoods are always bad, but impure lies are sometimes beneficial. Despite Socrates' insistence that he is not saying anything deep, his distinction is far from straightforward. Nevertheless, in order to determine why some falsehoods are beneficial and why some are always harmful, we must understand what exactly true falsehoods are and how they differ from impure lies.

In this paper, I argue that true falsehoods are a restricted class of false beliefs about ethics: they are false beliefs about how one should live and what one should pursue. I refer to these beliefs as "normative commitments." False normative commitments are always pernicious because they create and sustain psychological disharmony. Unlike true falsehoods, impure lies can be about anything. Nevertheless, they are only beneficial when they help produce and sustain true normative commitments. I argue that the upshot of this is that practical concerns have a kind of primacy over theoretical concerns. ${ }^{2}$

\section{TRUE FALSEHOOD AND IMPURE LIE}

The text (viz., 382a-d) is situated at the end of Book 2; Socrates and Adeimantus have been discussing the merits of the current educational system,

1. The translations are my own; however, I have leaned heavily upon Grube/Reeve 1997. The Greek texts I have used are from Burnet 1900-1907.

2. I should note that I will not focus on the political question of whether the lies in the Republic make Plato's government unjust. Rather, I shall focus on the ethical and epistemic question concerning Plato's attitude toward tolerating false beliefs. For discussions on the role of deception in the political realm, see Annas 1981, 106-7, 167; Brickhouse and Smith 1983; Page 1991; Popper 1966; Reeve 1988, esp. chap. 4; Taylor 1999.

[C 2017 by The University of Chicago. All rights reserved] 0009-837X/17/11201-0001\$10.00 
which centers around the poems of Hesiod, Homer, and others. Socrates assesses how the poets depict the gods and whether this account is both true and proper for educational purposes. Socrates examines three aspects of the gods as presented by the poets. First, the poets represent the gods as causing both badness and goodness (379a-380a). Socrates finds this objectionable, arguing that because the gods are completely good, they can only cause goodness (379c). Second, the poets depict the gods as changing forms (380d). Socrates finds this problematic because the gods cannot alter themselves. The gods are already in the best condition; any alteration from that condition would be to change them into something worse $(381 b-c)$. Third, the poets represent the gods as deceiving humans by presenting themselves as something that they are not. Socrates asks, "But may we suppose that while the gods themselves are incapable of change, they make us believe that they appear in many shapes, deceiving and practicing magic upon us?" (381e8-10). Adeimantus responds, "Perhaps" (381e11). Adeimantus' response surprises Socrates and leads him to

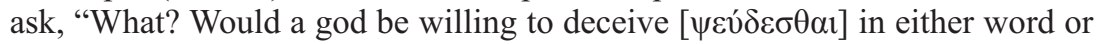
deed, by presenting an illusion?" (382a1-2).

When Adeimantus expresses uncertainty (382a3), Socrates attempts to identify a kind of deception or falsehood that no god or human would accept. Socrates says, "Don't you know that all gods and humans hate at least the true

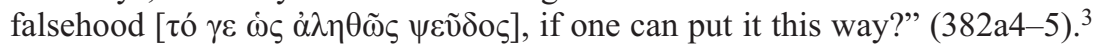
The paradoxical name, "true falsehood" ( $\dot{\omega} \varsigma \dot{\alpha} \lambda \eta \theta \tilde{\omega} \varsigma \psi \varepsilon \tilde{v} \delta \circ \varsigma)$, confuses Adeimantus (382a6). Socrates clarifies himself by explaining that "no one willingly

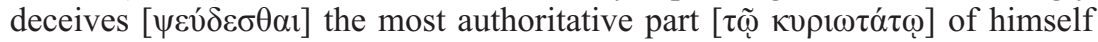
and about the most authoritative things $[\pi \varepsilon \rho \grave{\imath} \tau \grave{\alpha} \kappa v \rho \iota \omega ́ \tau \alpha \tau \alpha]$, but everyone most of all fears accepting it [viz., falsehood] there" (382a7-9). ${ }^{4}$ Understandably, Adeimantus is still quite puzzled (382a10).

Socrates attributes this confusion to Adeimantus mistakenly thinking that he is saying something profound or holy ( $\sigma \varepsilon \mu \nu$ ó $)$ ). Socrates explains that he sim-

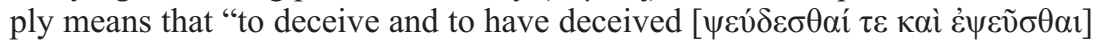

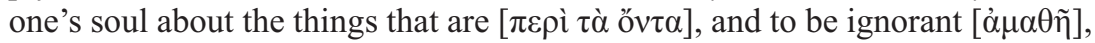

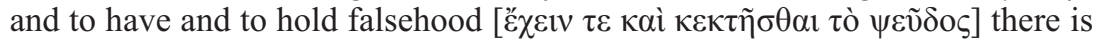
what everyone would least accept and would most hate in their soul" (382b15). Surprisingly, Adeimantus expresses that he understands (382b6).

Now that Socrates has Adeimantus' agreement, he attempts to justify his use of the paradoxical name "true falsehood" by contrasting it with a "not altogether

3. The Greek term $\psi \varepsilon \tilde{\delta} \delta o \varsigma$ can mean "lie" or "falsehood." Because "falsehood" is more of a neutral term than "lie," I shall translate $\omega \varsigma \dot{\alpha} \lambda \eta \theta \tilde{\omega} \varsigma \psi \varepsilon \tilde{\delta} \delta$ o $\varsigma$ as "true falsehood." Note that further below I will defend this interpretation when I argue that "true falsehoods" are really false beliefs about the most authoritative things.

4. At $7.535 \mathrm{~d}-\mathrm{e}$, Socrates says that the philosopher rulers are to hate both voluntary and involuntary falsehoods; cf. Leg. 730c. One might think that this is a continuation of the taxonomy of falsehoods at $382 \mathrm{a}-\mathrm{d}$ because at 382a-d Socrates discusses voluntary falsehoods. However, I do not think that Socrates means anything technical in his use of voluntary and involuntary falsehoods at 535d-e. I think Socrates simply means that the rulers ought to hate both saying something false without knowing it is false and saying something false while knowing it is false (i.e., lying). The idea is that the rulers should develop negative dispositions to falsehoods generally (cf. $474 b-475 c, 485 c-d, 490 a-c, 501 d)$. This is somewhat paradoxical because the rulers must lie in order to benefit the city (cf. 3.389). Nevertheless, the point seems to be that if the rulers dislike lying they will only lie when it is truly necessary and beneficial; cf. Annas 1981, 107, 166-67; Brickhouse and Smith 1983, 84; Schofield 2007, 148. 


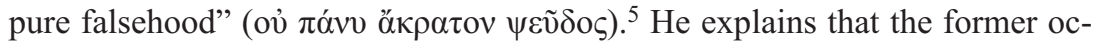
curs when one has ignorance in one's soul (382b7-9), while the latter is a "kind

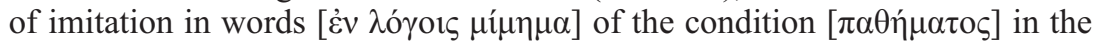

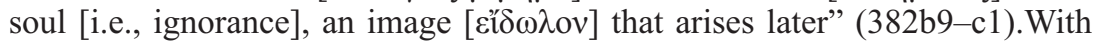
this distinction in place, Socrates explains that the "real falsehood" ( $\tau \tilde{\omega}$ o ov $v \imath$ $\left.\psi \varepsilon \tilde{v} \delta \sigma_{5}\right)$ is hated by both gods and humans (382c3-4), whereas the falsehood in words is not always hated by humans (but is by gods). Socrates likens falsehood in words to a useful drug, which can be used for preventing the ignorant or mad from doing bad (382c6-10). ${ }^{6}$ Additionally, Socrates explains that when discussing ancient stories that one is ignorant of (cf. 376e-378e) falsehood can be useful when it is as close to the truth as possible (382d1-3). ${ }^{7}$

Socrates is distinguishing between a "true" ( $\dot{\omega} \zeta \dot{\alpha} \lambda \eta \theta \tilde{\omega} \varsigma)$ or "real [ $\tau \tilde{\omega}$ ö $v \tau 1]$ falsehood" and an imitative falsehood that is "not altogether pure" (ov $\pi$ óvv

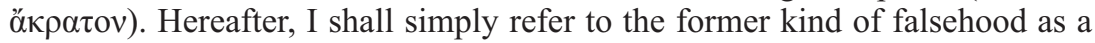
"true falsehood" and the latter kind of falsehood as an "impure falsehood." Socrates' explanation of the distinction is convoluted, and thus warrants a careful analysis. It will be helpful to begin with a general summary of the distinction. True falsehoods and impure falsehoods differ in their location, ontology, content, and effect. For instance, Socrates says that true falsehoods are located

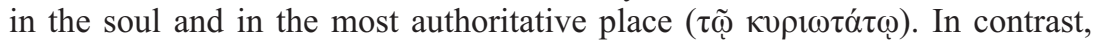

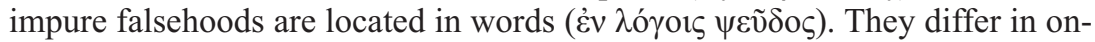
tology to the extent that true falsehoods are real ${ }^{8}$ and involve actual ignorance, while impure falsehoods are imitative and merely appear as real falsehoods. Socrates describes true falsehoods as being about the most authoritative things ( $\pi \varepsilon \rho \grave{~} \tau \grave{\alpha} \kappa v \rho i \omega ́ \tau \alpha \tau \alpha$ ), but does not specify the content of impure falsehoods. True falsehoods are always worthy of hatred, and thus are never useful. However, impure falsehoods are not always worthy of hatred to the extent that they are sometimes useful. ${ }^{9} \mathrm{~A}$ visual representation of these distinctions is found in Table 1 below.

Now that we have a clear overview, we can begin to examine each aspect in more detail. Let us begin with the categories of location and ontology. As I just explained, Socrates says that true falsehoods are real and are located in the soul and the most authoritative part of oneself. However, it is unclear what exactly this means. There are two possible interpretations: Either the soul is the most authoritative part of oneself, or the most authoritative part of oneself is a specific part of the soul, such as the reasoning part of the soul. Both

5. Note that eventually I will argue that "impure lie" is a better translation than "impure falsehood." How-

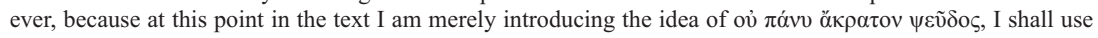
the phrase "impure falsehood."

6. Socrates continues the drug metaphor at $3.389 \mathrm{a}-\mathrm{c}$ when he asserts that just as only physicians should prescribe drugs, only philosopher-rulers should tell lies in the city. Following this, at $459 \mathrm{~d}-460 \mathrm{c}$, Socrates applies the drug metaphor when developing the "rigged sexual lotteries."

7. For a discussion of what stories Socrates might be referring to, see Belfiore 1985.

8. Hence the name "true" or "real falsehood."

9. At 382d-382e, Plato makes it clear that no falsehood could ever be useful to the gods. This demonstrates a way in which gods differ from humans. Impure falsehoods can be useful to humans, but can never be useful to the gods. 
TABLE 1. BASIC DifFERENCES BETWEEN THE TRUe FALSEHOOD AND THE IMPURE FALSEHOOD

\begin{tabular}{lllll}
\hline \hline & \multicolumn{1}{c}{ Location } & Ontology & \multicolumn{1}{c}{ Content } & \multicolumn{1}{c}{ Effect } \\
\hline $\begin{array}{l}\text { True } \\
\text { falsehood }\end{array}$ & $\begin{array}{l}\text { Soul, the most } \\
\text { authoritative } \\
\text { part of oneself }\end{array}$ & Real & $\begin{array}{l}\text { About the most } \\
\text { authoritative } \\
\text { things }\end{array}$ & $\begin{array}{l}\text { Always harmful, } \\
\text { never beneficial }\end{array}$ \\
$\begin{array}{l}\text { Impure } \\
\text { falsehood }\end{array}$ & Words & Imitative & $?$ & $\begin{array}{l}\text { Sometimes harm- } \\
\text { ful, sometimes } \\
\text { beneficial }\end{array}$ \\
\hline
\end{tabular}

interpretations have textual support; ${ }^{10}$ nevertheless, for the purposes of this paper, not much will depend on settling this dispute, and thus we can leave the issue in a stalemate.

The more pressing question is: What kind of things are true falsehoods? The most straightforward answer is that true falsehoods are false beliefs. This is the most obvious answer because true falsehoods are located in the soul, and beliefs are the psychological attitudes that are standardly understood as being true or false.

However, there is a notable objection to this reading. Christopher Gill argues that Socrates is using the terms "true" and "false" in a nonstandard (i.e., nonpropositional way). ${ }^{11}$ For instance, he says that "while such a state consists, in part, in having false ethical beliefs, it is clear from the larger context that such 'falsehood' is a property of the personality as a whole ... Correspondingly, 'truth' (at least, 'truth in the psyche') must also be a state of the whole personality and not just a property of statements or beliefs." 12 In support of this interpretation, Gill cites the fact that Socrates uses the terms "true" and "false" in other nonstandard ways in the Republic. ${ }^{13}$ For instance, Socrates describes god as being true in deed and word (382e8) and says that pleasures can be "true" and "false" (585d-586e; cf. Phlb. esp. 40c-41a).

Nevertheless, the evidence in favor of Gill's reading is lacking. First, in both of these passages (i.e., $382 \mathrm{e} 8,582 \mathrm{~d}-586 \mathrm{e}$ ) it is not obvious that it is necessary to read "true" and "false" in nonstandard ways, and it is possible to make sense of "true deeds" or "true pleasures" in a way that is compatible with standard accounts of truth. For example, in describing the gods as "true in deed," Soc-

10. For instance, when Plato divides the soul into parts in Book 4, he makes it clear that reason is supposed to have the most authority in the soul-it is supposed to control the spirited and appetitive parts. This lends credence to thinking that the most authoritative part of a person is the reasoning part. However, there are two things that tell against this interpretation. First, Plato has yet to divide the soul in Book 2. Second, and more importantly, Plato thinks that the soul, as a whole, has authority over the body, which suggests that Plato might be thinking of the most authoritative part of oneself as the soul in its entirety.

11. Brickhouse and Smith $(1983,86)$ also defend an extended use of "true" in the Republic. For a criticism, see Woolf 2009, 17.

12. Gill 1993, 45 .

13. Gill 1993, 45 n. 15. 
rates might simply be conveying the idea that the gods are honest and do not deceive or manipulate humans. Second, and more importantly, even if we are forced to interpret these passages (i.e., $382 \mathrm{e} 8$ and 582d-586e) as using a nonstandard account of truth, this does not force a nonstandard reading of truth in the notion "falsehood in the soul." There is nothing inconsistent in Socrates using a nonstandard account of truth to talk about "true deeds" or "true pleasure" and using a standard account of truth to talk about "falsehood in soul." Without any further reasons for entertaining an extended use of truth when interpreting falsehood in the soul, it is best to interpret falsehood in the soul simply as false beliefs.

In contrast to true falsehoods, impure falsehoods are located in words and are an imitation of ignorance. This seems to suggest that impure falsehoods are verbal assertions with false content. If we understand these false verbal assertions as lies told by people who know the truth, ${ }^{14}$ then we have a clear explanation for the imitative nature of impure falsehoods. ${ }^{15}$ For example, suppose Felipe lies to Sarah by telling her that Michael Jordan never played for the Chicago Bulls. Felipe does not actually believe this; he knows that Michael Jordan played for the Chicago Bulls. However, in order for Felipe's lie to be successful, his assertion has to appear to represent his actual beliefs. That is, he must appear to Sarah as someone who actually believes that Michael Jordan never played for the Chicago Bulls, which is to say that he must imitate being ignorant. ${ }^{16}$ Hence, I argue that the contrast between true falsehoods and impure falsehoods is between false beliefs and verbal lies; true falsehoods are false beliefs, while impure falsehoods are verbal lies; because of this, for the remainder of the paper I will use the term "impure lie" to refer to ov $\pi$ óvv

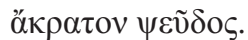

Many scholars, however, hold a different opinion; they argue that the fundamental difference between true falsehoods and impure lies is that impure lies are false beliefs about unimportant things and thus are beneficial (or at the very least, not devastating to an agent), while true falsehoods are false beliefs about important things, and thus always harm an agent. ${ }^{17} \mathrm{I}$ disagree with this interpretation for

14. I am making this qualification because a lie does not necessarily involve telling something false. For example, even if a verbal assertion is true, it is still a lie if the person asserting it believes that it is false and intends to deceive someone by asserting this statement.

15. Cf. Adam 1963, ad loc., 382b. Eric Brown has suggested that impure falsehoods might be imitative because they are linguistic as opposed to being imitative because they are lies told by someone who grasps the truth. This is an interesting suggestion, but all of the references to impure falsehoods in the Republic involve lies being told by people who grasp the truth (or at the very least, are aware they are not telling the full truth); cf. $3.389 \mathrm{a}-\mathrm{c} ; 5.459 \mathrm{~d}-460 \mathrm{c}$. Additionally, one advantage of my interpretation is that it can capture the impurity of impure falsehoods - they are impure because they are combined with truth. Ultimately, however, not much turns on this specific issue.

16. Simpson (2007, 345-46) argues that verbal falsehoods are not lies, but deception. Simpson maintains that lies involve a betrayal of trust, while deception does not necessarily involve this. However, it is not clear that Socrates has this distinction in mind. Moreover, even if we assume for the sake of argument that Socrates is operating under this distinction, it seems that some of the impure lies involve a betrayal of trust, such as the rigged sexual lottery $(5.459 \mathrm{~d}-460 \mathrm{c})$.

17. E.g., Reeve 1988, 210: "[A verbal lie] is not an 'altogether pure lie' because it does not in fact mislead about the good ... Clearly, the ruler's lies here are the verbal kind, for only they were earlier allowed to be useful and beneficial." Simpson 2007, 345: "A verbal falsehood misrepresents only unimportant things." See also Lear 2006. 
two reasons: First, it conflates the "content" and "effect" with the "location" and "ontology." From 382a-d, it is clear that Socrates means to keep these things separate. Second, and more importantly, at 382c6-10, Plato makes it clear that impure lies are not always useful, but are only sometimes useful. Hence, a generic feature of impure lies cannot be that they are useful, since this is not always the case.

Although the contrast between true falsehoods and impure lies is between false beliefs and verbal lies, it is a mistake to think that all false beliefs are true falsehoods. ${ }^{18}$ This interpretation is problematic for two reasons. First, Plato makes it clear that true falsehoods are about the most authoritative things, which indicates that true falsehoods are false beliefs restricted to a certain domain (i.e., the most authoritative things). Second, Plato makes it clear that lies are sometimes beneficial (i.e., impure lies). Presumably, these lies are beneficial because of the false beliefs that they produce and sustain. For example, when Felipe lies to Sarah saying that $p$, this lie can only be beneficial for Sarah if she forms the false belief that $p$. In other words, there is a symmetry between the lies that are beneficial or harmful to tell and the false beliefs that are beneficial or harmful to believe, such that beneficial lies produce beneficial false beliefs and harmful lies produce harmful false beliefs. Call this the "symmetry thesis."

With this in mind, we can distinguish between four kinds of falsehoods: false beliefs that are sometimes beneficial and sometimes harmful to possess (i.e., contingent falsehoods), ${ }^{19}$ false beliefs that are always harmful and never beneficial to possess (i.e., true falsehoods), lies that are sometimes beneficial and sometimes harmful to tell (i.e., impure lies), and lies that are always harmful and never beneficial to tell (i.e., impure lies).

Table 2 provides a visual representation of the various distinctions. As one can see, the content of the falsehood (either a lie or a belief) plays a fundamental role in determining whether the falsehood is necessarily harmful or contingently harmful. When the falsehood is about the most authoritative things it necessarily is harmful. Nevertheless, if the falsehood is about something else, then the falsehood can be harmful or beneficial depending on various circumstances. Because of this, we must determine what the most authoritative things are. This is the task of the next section.

\section{The Most Authoritative Things}

There are two plausible candidates for what Socrates means by the most authoritative things at $2.382 \mathrm{a}-\mathrm{d}$. They are either the old Socratic issues of the early dialogues (such as ethical considerations about how one should live), or they are they are the Platonic issues that concern metaphysical or philosophical matters (such as the Forms). In other words, the question is: Does a true falsehood involve having a false belief about basic ethical facts, or does it involve being ignorant of the Forms? In this section I shall argue that the former provides the best interpretation. I shall proceed by first giving a positive argument in defense of this view. Following this, I shall explain why this position is stronger than the latter interpretation.

18. At times Annas $(1981,107)$ and Schofield $(2007,144-47)$ appear to adopt such a position.

19. This label is my own insofar as Plato does not provide a name for this category. 
TABLE 2. FOUR TYPES OF FALSEHOODS IN THE REPUBLIC

\begin{tabular}{llllll}
\hline \hline & Location & Ontology & Form & \multicolumn{1}{c}{ Content } & \multicolumn{1}{c}{ Effect } \\
\hline $\begin{array}{l}\text { True } \\
\text { falsehood }\end{array}$ & $\begin{array}{l}\text { Soul/ } \\
\text { reason? }\end{array}$ & Real & Belief $\begin{array}{l}\text { About the most } \\
\text { authoritative } \\
\text { things }\end{array}$ & $\begin{array}{l}\text { Always harmful, } \\
\text { never beneficial }\end{array}$ \\
$\begin{array}{lllll}\text { Contingent } \\
\text { falsehood }\end{array}$ & $\begin{array}{l}\text { Soul/ } \\
\text { reason? }\end{array}$ & Real & Belief & $\begin{array}{l}\text { Not about the } \\
\text { most authorita- } \\
\text { tive things }\end{array}$ & $\begin{array}{l}\text { Sometimes harm- } \\
\text { ful, sometimes } \\
\text { beneficial }\end{array}$ \\
Impure lie & Words & Imitative & Lie & $\begin{array}{l}\text { About the most } \\
\text { authoritative } \\
\text { things }\end{array}$ & $\begin{array}{l}\text { Always harmful, } \\
\text { never beneficial }\end{array}$ \\
& Words & Imitative & Lie & $\begin{array}{l}\text { Not about the } \\
\text { most authorita- } \\
\text { tive things }\end{array}$ & $\begin{array}{l}\text { Sometimes harm- } \\
\text { ful, sometimes } \\
\text { beneficial }\end{array}$ \\
\hline
\end{tabular}

However, before I move on, I need to clarify what might be a source of confusion. The question I am asking is not whether some ethical truths are metaphysically independent of the Forms. Rather, the question is: Do you have a true falsehood if you have a false belief about certain ethical matters? Or, do you have a true falsehood if you are ignorant of the Forms? Notice that if you are ignorant of the former, you are necessarily ignorant of the Form of the Good because, presumably, knowledge of the Form of the Good entails grasping basic ethical truths. However, the inverse is not true, to the extent that you can have a true belief about a basic ethical fact while being completely ignorant of the Form of the Good. For instance, Susan can grasp that she should help her elderly neighbor carry his groceries into his apartment without knowing anything about the Form of the Good. This holds true even if the Form of the Good grounds the fact that helping her elderly neighbor is a good action.

Fundamentally, what is at stake in this debate is how damning the ignorance of the non-philosophers is. From Socrates' discussion at $2.382 \mathrm{a}-\mathrm{d}$ it is clear that true falsehoods are the worst and most hated kind of falsehood or ignorance one can possess. Thus, if true falsehoods involve ignorance or false beliefs about the Forms, then this bodes much worse for the non-philosophers because they do not have knowledge of the Forms. However, if true falsehoods involve ignorance or false beliefs about basic ethical facts, which non-philosophers are capable of grasping, then Plato has a much more optimistic view of non-philosophers in the Republic insofar as they do not possess the worst kind of falsehood-namely, the true falsehood. ${ }^{20}$

20. To be clear, I do not think that what is at stake is whether or not Plato's ethical theory can exist apart from the Forms. On the "ethical reading," the Form of the Good still provides the metaphysical grounds for good 


\section{A. Basic Ethical Facts}

The key to understanding what Socrates means by the most authoritative things is found in the passages that immediately precede and follow 382a-d. In Book 2, just before the introduction of the term "true falsehood," Socrates complains to Adeimantus that the poets depict the gods acting immorally. He says, "Telling

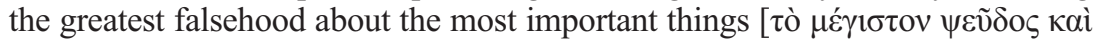
$\pi \varepsilon \rho i ̀ ~ \tau \tilde{\omega} \nu \mu \varepsilon \gamma i ́ \sigma \tau \omega v]$ doesn't make a fine story" (377e6-7). The example he gives is of Uranus, Cronus, and Zeus acting unjustly (377e-378a). The story is not "fine," and the reason it is not fine is because it depicts the gods acting in despicable ways, and this sends the wrong message to the audience of the poems (378b). ${ }^{21}$

This passage suggests that the most important things have to do with ethics and how justice is portrayed. If the greatest of gods is depicted as acting unjustly, Socrates worries that stories like this will make the citizens believe that acting unjustly is acceptable-perhaps even praiseworthy. This will lead the citizens to cultivate the wrong psychological dispositions; as a result, they will mistake what is good for bad and bad for good.22

This worry is echoed in Socrates' criticism of the poets in Book 3 (392b1-6):

Because I think we'll say that what poets and prose-writers tell us about the most important matters concerning human beings $[\pi \varepsilon \rho \grave{\alpha} \dot{\alpha} v \theta \rho \omega ́ \pi \omega \nu \tau \grave{\alpha} \mu \varepsilon \dot{\gamma}(\sigma \tau \alpha]$ is bad. They say that many unjust people are happy and many just ones wretched, that injustice is profitable if it escapes detection, and that justice is another's good, but one's own loss. I think we'll prohibit these stories and order the poets to compose the opposite kind of poetry and tell the opposite kind of tales.

In this passage, the most important matters concerning human beings are explained in terms of how justice relates to happiness. It is dangerous if the citizens are taught that justice leads to unhappiness and that injustice leads to happiness. Stories like this will mislead citizens about what is good and bad, thereby leading them to cultivate bad psychological dispositions.

Hence, in the passages that surround $382 \mathrm{a}-\mathrm{d}$, "the most important things" ( $\tau \grave{\alpha} \mu \varepsilon ́ \gamma 1 \sigma \tau \alpha)$ are ethical matters. ${ }^{23}$ However, what reason do we have for thinking that "the most important things" ( $\tau \dot{\alpha} \mu \varepsilon \dot{\gamma} 1 \sigma \tau \alpha)$ are "the most authoritative

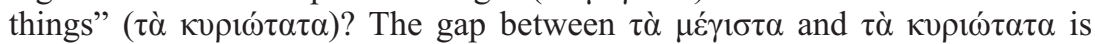
bridged in Book 3. Having just discussed the types of music and poetry that are beneficial for education, Socrates asserts that music and poetry are the most

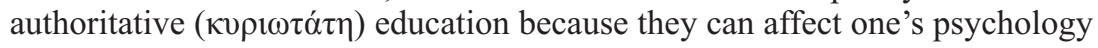

actions. Furthermore, on the "ethical reading," the philosophers are still in a better state than the non-philosophers insofar as they understand why actions are wrong.

21. Page $(1991,9)$ takes this to show that the "biggest things" ( $\left.\tau \grave{\alpha} \mu \varepsilon \dot{\gamma} \gamma \_\tau \alpha\right)$ have to do with the cosmic order that "dwarf the specifically human." However, this interpretation misses the point of the passage, which is primarily about education. Plato is concerned that because humans admire the gods, humans will want to behave like the gods. Hence, if humans hear that the gods act unjustly, humans will act unjustly. This is why these stories deal with the most important things. Cf. 377a-b, 378a-b, 380b-c, 381e, 386a-c, 388b-d, 389d-e, 391e.

22. At $377 \mathrm{~d}-\mathrm{e}$, Socrates condemns these stories saying that they "create a bad image of what the gods and heroes are like, just as a painter might paint a picture that is not at all like the things he is trying to paint." One might take this to demonstrate that Socrates' criticism is not that these stories cause harmful dispositions, but that they are simply inaccurate. However, 377e-378a reveals that this cannot be the case, because even if these stories were true, they "should be passed over in silence and not told to foolish and young people." This passage will be discussed in greater detail in section 4 .

23. Cf. Leg. 890 b. 
in the greatest way (401d-e). Music and poetry do this in two ways: First, because rhythm and harmony permeate the inner part of the soul more than anything else, they can affect it in the strongest way. Second, a proper education in music and poetry will give one the ability to recognize what is fine and good, even if one does not yet understand the reason why these things are fine and good (401d-402b). ${ }^{24}$ Thus, music and poetry are the most authoritative form of education because a proper education in music and poetry supplies one with the basic psychological dispositions necessary for living well. ${ }^{25}$ This was the same reason why the stories at $2.377 \mathrm{e} 6-7$ and $3.392 \mathrm{~b} 1-6$ are the most important - they concern fundamental ethical issues about how to live. Therefore, I hold that the most authoritative things concern ethical facts about how to live. This is not a revisionary perspective, for it is just the kind of thing we see in Plato's early dialogues. For example, in the Apology, Socrates tells us that he has spent his life trying to persuade others that their primary concern in life should be the condition of their soul and whether it is good or not. ${ }^{26}$

\section{B. The Forms}

As I previously mentioned, an alternative interpretation is that the most authoritative things are metaphysical or philosophical things, such as the Forms. Hence, on this reading true falsehoods are false beliefs about these metaphysical things. Before I object to this position, I should note that this view has some plausibility. The most worked out defenses of such a position are found in both David Simpson's and Raphael Woolf's respective work. ${ }^{27}$ They point out that in Book 6, Soc-

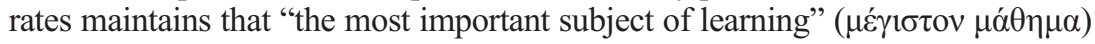
is the Form of the Good (503e-505a). Additionally, in Book 7, Socrates describes the Form of the Good as having authority ( $\kappa$ $\rho 10 \varsigma$ ) in the intelligible realm and providing truth and understanding (517c). This provides some evidence for thinking of the Forms as the most authoritative things. Additionally, Plato makes it clear in the Republic that understanding the Forms is evaluatively more important than possessing mere true beliefs about basic facts. This interpretation has a clear explanation for why this is the case - the Forms are the most authoritative things. Moreover, at 382b1-5, Socrates says that true falsehoods

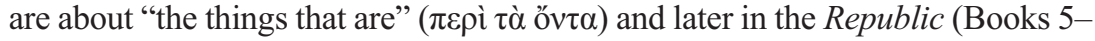
7), Plato argues that "the things that are" are the Forms. Hence, one could take this as evidence that Plato is talking about the Forms at 382b1-5.

Nevertheless, this interpretation faces three serious problems. First, the fact that Socrates describes the Form of the Good as "important" or as an "authority" does not vindicate the Forms interpretation over the ethics interpretation because the Form of the Good is highly relevant to particular ethical matters. In other words, these passages can also support the reading that the most authoritative things are ethical facts concerning how to live.

24. This aspect of education will be discussed in more detail in section 5 below.

25. Cf. 546 d.

26. Cf. especially Ap. 22d, 28a, 30a-b; Grg. 521d-522e. We also see this line of thought in Plato's Middle and Late dialogues; cf. Soph. 230e; Plt. 302b, 308b; Leg. 689a-c, 731c3-7.

27. Simpson 2007; Woolf 2009; see also De Chiara-Quenzer 1994, 34. 
Second, at 382b1-5, Socrates emphasizes that he is not saying anything $\sigma \varepsilon \mu \nu$ ó $\varsigma$ when discussing true falsehoods. The Greek word $\sigma \varepsilon \mu \nu$ ó $\varsigma$ means holy, profound, or majestic, and it is often used to describe the gods and other divine things. ${ }^{28}$ This poses a significant problem for reading "the most authoritative things" as the Forms because Plato describes the Forms as divine. For example, in Book 6, Socrates explains that "by consorting with what is ordered and

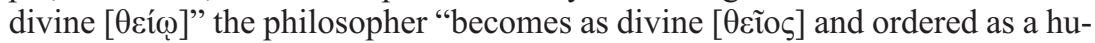
man can be" (500c9-d2). I take it to be uncontroversial that the ordered and divine things that the philosopher is consorting with are the Forms. After all, a few lines later Socrates describes the study of the Form of the Good as the most important subject for philosophers (503e-505a). ${ }^{29}$ Additionally, in Book 7 , Socrates explains that once out of the cave, the philosopher is able to look at divine images of the things that are (i.e., the Forms) (532c). Now, because the Forms are divine, and divine things are $\sigma \varepsilon \mu \nu$ ó $\varsigma$, it follows that the Forms are $\sigma \varepsilon \mu v$ ó $\varsigma$. This poses a serious problem for this interpretation because at 382b15 , Socrates makes it clear that in talking about true falsehoods he is not saying anything $\sigma \varepsilon \mu v o ́ c$.

Now one might object by arguing that when Socrates tells Adeimantus that he is not saying anything $\sigma \varepsilon \mu v$ ó, , Socrates is not referring to the quality or property of true falsehoods. Rather, Socrates is simply telling Adeimantus that he is overthinking his explanation of true falsehoods. In other words, true falsehoods might be false beliefs about things that are holy or majestic, but it does not follow from this that one's explanation of true falsehoods is profound or deep. $^{30}$

In response to this objection, I should point out that if Socrates is talking about the Forms at 382a-d, then his explanation of true falsehoods is even more elusive and cryptic than it first appears. This is because $382 \mathrm{a}-\mathrm{d}$ is sandwiched between discussions that are primarily about education and not about metaphysics. Thus, if Socrates is sneaking in complex metaphysical ideasideas that are not explained until much later in the text - then he should have asked Adeimantus to think harder because he is, in fact, saying something quite profound. This is powerful evidence against reading "the things that are" ( $\pi \varepsilon \rho i$ $\tau \grave{\alpha}$ öv $\tau \alpha)$ at $382 b 1-5$ as the Forms. ${ }^{31}$

Third, and most importantly, if true falsehoods are false beliefs about metaphysical things, such as the Forms, then it follows that it is always harmful to possess false beliefs about the nature of reality. Now, assuming that the symmetry thesis is true, if it is always harmful to possess false beliefs about the nature of reality, then it is always harmful to lie about the nature of reality. The problem with interpreting true falsehoods as false beliefs about the Forms

28. See the LSJ entry. Additionally, Plato sometimes uses $\sigma \varepsilon \mu v o ́ \varsigma$ and its cognates to refer to holy things; cf. Cri. 51a9; Soph. 249a1; Plt. 290d8, 290e7; Leg. 663d2. Plato also uses this term to express (sometimes ironically) that something is worthy of esteem; cf. Cra. 392a1; Tht. 150a3, 203e9; Phlb. 53d6; Symp. 199a3; Phdr. 258a6; Euthyd. 279a6, 303c8; Grg. 502b1, 511c5; Resp. 475b1; Menex. 235b2; Leg. 814e4.

29. Cf. Phd. $80 \mathrm{a}-\mathrm{b}$.

30. I thank Tyler Paytas for raising this objection.

31. One might push back and say that Socrates is merely being ironic in an attempt to win Adeimantus' sympathy. I believe, however, that this makes for a weaker and less interesting interpretation and that it is far more interesting as a matter of interpretative method to take Socrates at his word. 
is that in the "allegory of the cave" philosophers lie to the non-philosophers about the nature of reality. For instance, Socrates explains that disastrous social results could ensue if the non-philosopher were told that the sights and sounds were not real (517a3-6):

\begin{abstract}
Soc: Wouldn't it be said of him [viz., the philosopher] that he'd returned from his upward journey with his eyesight ruined and that it isn't worthwhile even to try to travel upward? And, as for anyone who tried to free them [viz., the non-philosophers] and lead them upward, if they could somehow get their hands on him, wouldn't they kill him?
\end{abstract}

Glau: They certainly would.

One lesson to draw from this passage is that philosophers should not attempt to teach non-philosophers about the Forms. The non-philosophers do not have the intellectual capacity nor the proper education to understand the Forms. If a philosopher attempts to teach a non-philosopher about the Forms, the nonphilosopher would likely think that the philosopher was foolish and that his nonsense teachings are dangerous to the city. ${ }^{32}$ Hence, it is best if philosophers do not attempt to disrupt the non-philosophers' mistaken beliefs about nature of reality by telling them the truth. If the philosophers are to guide society, they have to do it by telling falsehoods. Some of these falsehoods will be about the nature of reality, and these false beliefs will benefit the non-philosophers.

This is a point that Woolf fails to see; for instance, he says, "That someone is not philosophical, by contrast, makes it not bad but pointless to impart certain truths, namely the philosophical ones; for they could not be grasped by such a person." 33 I disagree; 517a3-7 suggests that it is bad to try to communicate these truths; but it does not suggest that it is pointless. One of the upshots of this is that sometimes we ought not to tell the truth even when it is about divine things, such as the Forms. That is, sometimes we should not be gadflies (cf. Ap. $30 \mathrm{e})$.

One might object by arguing that although philosophers are not telling nonphilosophers the truth about the Forms or the nature of reality, it is not the case that they are straightforwardly lying to them about the Forms and reality. For example, if philosophers fail to tell non-philosophers the whole truth about reality, does it follow that they are lying about reality? By my lights, this seems to be a paradigm example of lying. ${ }^{34}$ After all, philosophers are intentionally causing non-philosophers to have and to continue to have false beliefs about facts that they know. However, a full discussion of what exactly constitutes a lie will lead us too far astray; what is essential for the purposes of this paper is that philosophers make false verbal assertions that produce and sustain false beliefs about the nature of reality in non-philosophers, and these false assertions produce a better outcome than if philosophers were to tell the truth about these things.

32. One might object that at 480a the non-philosophers are not supposed to be angry at the philosophers when they speak the truth; however, 480 a does not actually say this. The passage only says that if non-philosophers take Socrates' advice they should not be angry in being called lovers of opinions rather than philosophers.

33. Woolf 2009, 21.

34. See Mahon 2007, 189-90. 
Independent of my arguments against the Forms reading, one might find it odd that on my reading "the things that are" at $382 \mathrm{~b}$ refers to ethical facts about how to live. One might wonder why Socrates is using descriptive language to refer to normative content. ${ }^{35}$ Admittedly, Socrates' use of "the things that are" at $382 \mathrm{~b}$ is strange. Nevertheless, it is possible to use descriptive language to talk about normative matters. Suppose, for instance, that the world is such that one ought to instantiate and promote goodness. Now suppose that it is also a fact of the world that certain dispositions and actions instantiate and promote goodness. If this is true, then there is a set of possible actions and dispositions that instantiate and promote goodness, and it is possible to be ignorant about this set of things. Consider a simple example. When I was a child, my father used to tell me that I ought to clean my room and that this is "just the way things are." In saying that this is "just the way things are," my father was using a descriptive claim about the facts of the world to make the normative claim that I ought to clean my room. Moreover, my reluctance about cleaning my room points to me being ignorant about "the way things are," according to my father. ${ }^{36}$

\section{ETHICAL BELIEFS}

In the previous section, I argued that it is better to interpret the most authoritative things as ethical matters rather than as philosophical or metaphysical things. However, we might wonder if all ethical beliefs count as being about "the most authoritative things" or if it is a particular subset. It will be helpful to begin by distinguishing between two types of ethical beliefs: "normative commitments" and "justifications." Normative commitments are beliefs about how one should live and what one should pursue, while justifications are beliefs about why certain normative commitments should be held. For example, suppose that agent $A$ judges that she should $\varphi$ for reason $R$. The justificatory belief is $R$, while the normative commitment is $A$ 's judgment that she should $\varphi$. Notice that it is possible for $A$ to judge correctly that she should $\varphi$ and for her justificatory belief, $R$, to be false. ${ }^{37}$

In what follows, I argue that true falsehoods are false normative commitments. I defend this claim by examining three beneficial false beliefs in the Republic. I should note, however, that I am not arguing that Plato explicitly makes this distinction. Rather, my point is that by analyzing various passages in the Republic, we can find this distinction in play.

35. I thank an anonymous referee for raising this interesting objection.

36. To be clear, I am not saying that one can derive an "ought" from an "is." I am merely saying that one can describe an "ought" as an "is."

37. We can further subdivide these ethical beliefs. For instance, justificatory beliefs can be divided into cognitive states with metaphysical content and cognitive states without metaphysical content. E.g., $A$ might believe that she should $\varphi$ because this promotes the greatest amount of happiness, or $A$ might believe that she should $\varphi$ because it instantiates the Form of the Good. Notice, that the latter involves more robust metaphysical commitments than the former. This distinction is not relevant for the purposes of this paper. Additionally, we can further distinguish between general ethical commitments concerning how one should behave and ethical particulars about how one should act at a very specific moment. The useful false beliefs that I discuss in this section fit the former kind of ethical belief better. I thank an anonymous referee for clarifying this issue. 
The first example occurs in Book 2 at 377e-378a. Socrates asserts that stories about the gods acting unjustly tell the greatest falsehood about the most important things. Following this, Socrates says, "But even if it were true, ${ }^{38}$ it should be passed over in silence and not told to foolish and young people" (378a2-4). ${ }^{39} \mathrm{In}$ this passage, Socrates is explicitly stating that even if it were true that the gods acted unjustly, people should not be told this (except in extreme circumstances). The context of the passage implies that the citizens should be told stories in which the gods always act justly, even if these stories are completely false. ${ }^{40}$

Socrates is willing to sacrifice the truth about the gods because he recognizes that the stories people hear about the gods influence the normative commitments people have. ${ }^{41}$ We can represent this belief-formation process with the following model:

\section{$A$ Reasons that:}

B1) I should emulate the gods.

B2) The gods $\varphi$.

NC) I should $\varphi$.

Now provided that the citizens form normative commitments in this way, Socrates is concerned that if it were the case that the gods acted unjustly and people knew this fact, people would form the false normative commitment that they should act unjustly. We can represent Socrates' concern as follows:

$A$ Reasons that:

B1) I should emulate the gods. (False) ${ }^{42}$

B2) The gods act unjustly. (True)

NC) I should act unjustly. (False)

Hence, because of this worry, even if it were true that the gods acted unjustly, the citizens should be told the falsehood that the gods never act unjustly. This false belief about the gods is beneficial because it will produce the true normative commitment that they should always act justly. This can be represented as follows:

\section{$A$ Reasons that:}

B1) I should emulate the gods. (False)

38. It is clear from the context that Socrates does not think that it is true. Cf. Leg. $941 \mathrm{~b}-\mathrm{c}$.

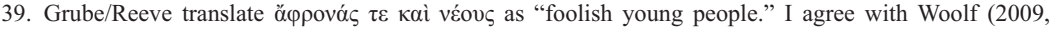
$12 \mathrm{n} .8$ ) that this passage should be translated as "foolish and young people." Plato explicitly includes adults in his discussion of music and poetry; cf. 378c6-d2, 380c1-2, 387b4.

40. Strictly speaking, Socrates does not actually say that they should be told a falsehood. He only says that they should not be told the truth. However, it can be inferred from the context that they will be told a falsehood about this.

41. Cf. 377a-b, 378a-b, 380b-c. Additionally, notice the similarity with the Euthyphro; Euthyphro makes all sorts of normative mistakes because of the stories he has heard about the gods. I thank G. Fay Edwards for reminding me of this.

42. Belief 1 is false because if the gods act unjustly, it is not the case that people should emulate the gods in this way. 
B2) The gods always act justly. (False)

NC) I should always act justly. (True)

The false justificatory belief in this example is that one should always act justly because the gods always act justly. ${ }^{43}$ However, Socrates is tolerant of this false belief because it will lead people to act rightly by giving them a true normative commitment. This suggests that Socrates is tolerant of false justifications when they produce true normative commitments.

The second example comes right after the first. Socrates asserts that he does not want the citizens told stories about the gods hating and warring with one another because this will make the citizens think that this behavior is appropriate. Because of this, Socrates proposes that the poets adopt new stories (2.378c6-d3):

But if we're to persuade our people that no citizen has ever hated another and that it's impious to do so, then that's what should be told to children from the beginning by old men and women; and as these children grow older, poets should be compelled to tell them the same sort of thing.

Socrates recognizes that people imitate behaviors that they take to be ordinary or normal (378b). If people are told stories about citizens never hating one another, they will think that it is abnormal to hate a fellow citizen, and this will lead them to judge that such behavior is inappropriate. We can represent the structure of the belief-formation process as follows:

$A$ Reasons that:

B1) I should act in ways that are ordinary and should not act in ways that are not ordinary.

B2) It is not ordinary to $\varphi$.

NC) I should not $\varphi$.

We can represent the beliefs that this story produces and sustains with the following model:

$A$ Reasons that:

B1) I should act in ways that are ordinary and should not act in ways that are not ordinary. (False)

B2) No citizen has ever hated a fellow citizen. That is, it is ordinary for citizens not to hate one another and it is not ordinary for them to hate one another. (False)

NC) I should not hate my fellow citizens. (True)

Although B1 and B2 are false, they play an instrumental role in producing the true normative commitment that citizens should not hate each other. Moreover, it is important to note that B2 does a better job at producing this true normative

43. Again, it is important to keep in mind that Plato does not actually think that the gods act unjustly, he is merely arguing that if it were the case, then people should not be told the truth. 
commitment than if people were told the truth about human behavior. For instance, imagine that the citizens were told: "Although it is impious to hate one another, this behavior is not that uncommon, for it is actually quite ordinary for humans to fight with each other." Provided that people formulate normative commitments based upon what is deemed ordinary or normal, such stories would lead citizens to the conclusion that it is permissible to sometimes hate one another. ${ }^{44}$

The third example is the infamous noble lie $(414 d-415 c) .{ }^{45}$ In Book 3, Socrates and Glaucon agree that in order to create the appropriate structure for their utopian city they need a creation story upon which to found the city. The citizens will be told that everything up until this point has been a dream ${ }^{46}$ and that while they were dreaming, their real selves were being created and nurtured inside the earth. Because the earth is their mother, they are all related. ${ }^{47}$ Despite the fact that all citizens are related, different citizens have different metals in their soul: some gold, some silver, some bronze, some iron, and some brass. The myth serves two fundamental purposes: First, it unifies the city by making the citizens think that they are all related. Second, it divides the city by putting the citizens into distinct classes. ${ }^{48}$ The unifying aspect benefits the citizens by facilitating harmonious relations among them. Additionally, it gives the auxiliaries and the ruling class a personal reason to care about the wellbeing of the producers, which in turn prevents the auxiliaries from bullying the weaker citizens $(416 a-b)$. The dividing aspect of the myth provides the members of different classes with an explanation for why members of different classes have different lifestyles and different political obligations.

Because there are two different aspects of the noble lie, I shall analyze each aspect separately. The unifying aspect develops or sustains the following three beliefs:

44. This demonstrates just how perceptive Plato is when it comes to human psychology. Today, psychologists are finding that the best way to change people's behavior toward the environment is to tell them how their peers behave in such situations. For instance, Goldstein et al. (2008) found that the best way to reduce the number of towels used by guests in a hotel was not to tell them that reusing towels helps the environment and that not reusing them harms the environment. Rather, it was more effective to tell guests that the majority of other guests in the hotel reused their towels.

45. There is an interesting question as to how Plato's attitude toward truth and falsehood in the Republic is similar and different to his attitude in the Laws. Schofield (2007, 161-62) suggests that it is quite similar to the extent that Laws 663d-664a seems to endorse something like "noble lies." Recently, David Lay Williams (2013) has argued that, unlike the Republic, the Laws does not endorse beneficial lies; cf. Leg. 730c. Although I believe Williams' argument is interesting, I ultimately think that Plato endorses the use of noble lies in the Laws in much the same way as he does in the Republic. That is, in the Laws like the Republic, Plato is willing to tolerate falsehoods insofar as they do not mislead about the most authoritative things. Additionally, because Plato is less obviously concerned with the Forms in the Laws, a strong case can be made for the claim that the most authoritative things in the Laws do not concern the Forms, but concern normative commitments.

46. Lear $(2006,32-33)$ insightfully points out how this aspect of the noble lie is epistemically revolutionary in the sense that it tells one that everything up until this point has been a dream. Lear, however, (2006, 33-34) mistakenly thinks that this aspect of the noble lie will teach citizens to recognize allegory as allegory. This, however, is an overinterpretation; this aspect of the noble lie is simply intended to erase the other myths so that the founders of the city can instill new myths.

47. Essentially, the rulers are inserting a false memory in the citizens. Surprisingly there is some empirical evidence that inserting false memories can be beneficial. For instance, Clifasefi et al. (2013) found that giving alcoholics the false memory that they had a horrible experience while drinking reduced their overall level of alcohol consumption.

48. For an interesting discussion of these ideas see Schofield 2009 and 2007; Bloom 1991, 365-67. 
$A$ Reasons that:

B1) I should care for my relatives. (True)

B2) All citizens are related to one another. (False)

NC) I should care for my fellow citizens. (True)

Socrates is cleverly playing off the natural belief that people should care for their relatives. Hence, by making the citizens falsely believe that they are all relatives, the citizens are led to the true normative commitment that they should care for their fellow citizens.

The separating feature of the noble lie has a similar structure. This aspect produces and sustains the following beliefs:

\section{$A$ Reasons that:}

B1) Some citizens have different metals in their soul. (False)

B2) People with different metals in their soul are suited to different tasks, such that people with metal $\gamma$ should $\varphi$. (False)

B3) I have $\gamma$. (False)

NC) I should $\varphi$. (True)

Beliefs 1-3 provide the relevant background and justification for the true normative commitment.

Each of these examples has roughly the same structure. ${ }^{49}$ The citizens are given false justifications in order to produce and sustain true normative commitments. ${ }^{50}$ This suggests that the most authoritative things are normative in nature and that true falsehoods are false normative commitments. ${ }^{51}$ Interpreting true falsehoods in this way provides a clear explanation for why true falsehoods are always hated by gods and humans. In Book 4, Plato equates justice to psychological health (444d-445b). He maintains that just actions create and sustain psychological health, while unjust actions produce psychological disharmony. Thus, true falsehoods are pernicious because normative commitments are inextricably tied to one's well-being. For example, if $A$ has a false normative commitment (i.e., a true falsehood), her false belief is going to lead her to act wrongly, and this is going to harm her well-being. Therefore, because $A$ 's well-being is tied to the ethical quality of her actions, it is the greatest error for $A$ to be mistaken about how she should live. However, it is much less of a concern if $A$ is mistaken about why she should perform an action, as long as the action she is performing is appropriate.

49. The other beneficial false beliefs in the Kallipolis have the same structure as well. For example, see Socrates' discussion of the communal living arrangements $(416 \mathrm{e}-417 \mathrm{~b})$ and the rigged sexual lottery $(459 \mathrm{~d}-460 \mathrm{c})$. I am omitting these examples merely to avoid unnecessary repetition.

50. Notice how this is suggested at 382c6-10: "Isn't it useful against one's enemies and one's so-called friends, when they are attempting, through madness or ignorance, to do something bad, doesn't it then become as a useful drug for preventing them?"

51. This aspect of my interpretation has some affinities with Page's $(1991,17)$ reading: "Only if lying did nothing else but frustrate normal human access to the truths required for good action could it be intrinsically objectionable." 


\section{THE PRIMACY OF THE PRACTICAL}

I have argued that Socrates is tolerant of false justificatory beliefs, but intolerant of false normative commitments. The upshot of this interpretation is that practical considerations have a kind of primacy over theoretical concerns. ${ }^{52}$ To see this, let us reexamine why Socrates considers music and poetry to be the most authoritative form of education. As I previously discussed, in Book 3, Socrates argues that one reason education in music and poetry is most authoritative is that it allows one to grasp that something is fine and good, before one understands the reason why it is fine and good (401d-402b). Socrates is distinguishing grasping that $\varphi$ is good from understanding why $\varphi$ is good. The latter is much more theoretically complex than the former. This is why education of the former precedes the latter and why only philosophers truly obtain an understanding of the latter. ${ }^{53}$

With this distinction in mind, let us turn to the beneficial falsehoods in the Republic. I have argued that Socrates is willing to tolerate false justificatory beliefs for the sake of producing true normative commitments. Normative commitments are practical in nature because they are beliefs about what one should pursue. For example, if $A$ has the true belief that she should $\varphi$, then $A$ will act rightly (assuming, of course, that she is not akratic or ignorant of some relevant empirical fact). In contrast, justifications are more theoretically robust because they are about the reasons why one takes an action to be right or wrong. ${ }^{54}$ For example, if $A$ believes that she should care for her fellow citizens and not hate them because it leads to a harmonious society and that this is good because harmony and unity are by their very nature good, then $A$ has a rather complex understanding of the ethical facts concerning this matter. However, if $A$ merely believes that she should care for her fellow citizens because she falsely believes that the citizens are her relatives, then $A$ has a rather shallow grasp of the ethical fact concerning this matter. This is because although $A$ grasps the "that," she misunderstands the "why." Each of the beneficial falsehoods in the Republic has this same structure: They mislead one about why something is right, in order to get one to form a true belief about the action that one should pursue. ${ }^{55}$ This demonstrates a way in which practical concerns have

52. This also undermines a traditional way of understanding the falsehoods in the Republic. Commentators often say that the falsehoods are false on the surface, but produce deeper and theoretically robust truth. For example, Lear (2006, 31-33) argues that impure falsehoods in the Republic are connected to the Greek word vं óvor $\alpha$, which means allegory, or under-thought. The idea is that the impure falsehoods are false on the surface, but have a deeper layer of truth, which they convey. Dorter $(1982,95)$, offers a similar interpretation saying, "The most famous instance of this kind of technique is the 'noble lie' of the Republic by which people are to be made to accept the true state of affairs not by being told the truth . . . but by being told a lie that symbolizes the truth and that would be easier to persuade them of." See also Ferrari 1989, 112; Morgan 2000, 164; Dorter $1982,7$. Perhaps, also see Gill 1993; Johansen 1998; Kamtekar 2006, 199; Reeve 1988, 209-10. My interpretation undermines this view because I argue that the beneficial falsehoods are about complex theoretical things and produce simple - albeit important-truths.

53. Cf. Arist. Eth. Nic. 1.4. 1095b3-8; for discussions, see Brown 2004, 286; Gill 1996a, 200; 1996b, chap. 4; 1985.

54. Kant held that for an action to have moral worth one must understand that the action accords with moral duty. That is, one must understand why such an action is the right action. See esp. Groundwork of the Metaphysics of Morals 4: 393-405.

55. There is an interesting comparison with Kant's account of reason. Kant maintained that practical reason has primacy over theoretical reason. By primacy Kant meant two things: First, if there is a conflict between the 
a kind of primacy over theoretical concerns - the fact that $p$ is false is far less important than the fact that believing that $p$ will get me to behave correctly, and this holds true even when that $p$ is about complex theoretical things, such as the Forms. ${ }^{56}$

\section{University of Missouri-Columbia}

two, practical reason overrides theoretical reason. Second, Kant maintained that theoretical reason was ultimately grounded by practical reason, and this is ultimately why practical considerations take precedence over theoretical concerns; see esp. Critique of Practical Reason 5: 120-22. For Plato, practical considerations have the former kind of primacy, but not the latter.

56. I received helpful feedback on a version of this paper at the 2014 spring meeting of the Indiana Philosophical Association. I thank the following people for their help with this paper: Nathan Adams, Anna Christensen, G. Fay Edwards, Robert Lamberton, Sarah Malanowski, Felipe Romero, Lewis Trelawny-Cassity, and Rachel Williams. In addition, I would like to thank the two anonymous referees as well as the editorial staff at $C P$. Lastly, I would like to extend a very special thank you to Eric Brown, Jason Gardner, and Tyler Paytas, who each read many drafts of this paper and offered very helpful comments.

\section{LITERATURE CITED}

Adam, James, ed. 1963. The "Republic" of Plato: Edited, with Critical Notes, Commentary, and Appendices $^{2} .2$ vols. Cambridge.

Annas, Julia. 1981. An Introduction to Plato's “Republic.” Oxford.

Belfiore, Elizabeth. 1985. Lies Unlike the Truth: Plato on Hesiod Theogony 27. TAPA 115: 47-57.

Bloom, Alan. 1991. Interpretive Essay. In The "Republic" of Plato: Translated with Notes and an Interpretive Essay. New York.

Brickhouse, Thomas C., and Nicholas D. Smith. 1983. Justice and Dishonesty in Plato's Republic. Southern Journal of Philosophv 21: 79-96.

Brown, Eric. 2004. Minding the Gap in Plato's Republic. Philosophical Studies 117: 275-302.

Burnet, John, ed. 1900-1907. Platonis Opera. 5 vols. Oxford.

Clifasefi, Seema L., Daniel M. Bernstein, Antonia Mantonakis, and Elizabeth F. Loftus. 2013. Queasy Does It: False Alcohol Beliefs and Memories May Lead to Diminished Alcohol Preferences. Acta Psvchologica 143: 14-19.

De Chiara-Quenzer, Deborah. 1994. To Lie or Not to Lie: Plato's Republic. Polis 13: 31-45.

Dorter, Kenneth. 1982. Plato's "Phaedo”: An Interpretation. Toronto.

Ferrari, G. R. F. 1989. Plato on Poetry. In The Cambridge History of Literary Criticism, vol. 1, ed. G. A. Kennedy, 92-141. Cambridge.

Gill, Christopher. 1985. Plato and the Education of Character. Archiv für Geschichte Der Philosophie: 1-26.

1993. Plato on Falsehood-Not Fiction. In Lies and Fiction in the Ancient World, ed. Christopher Gill and T. P. Wiseman, 38-87. Exeter.

- 1996a. Ethical Reflection and the Shaping of Character: Plato's Republic and Stoicism. Proceedings of the Boston Area Colloquium in Ancient Philosophv 12: 193-225.

1996b. Personality in Greek Epic, Tragedy, and Philosophy: The Self in Dialogue. Oxford.

Goldstein, Noah J., Robert B. Cialdini, and Vladas Griskevicius. 2008. A Room with a Viewpoint: Using Social Norms to Motivate Environmental Conservation in Hotels. Journal of Consumer Research 35: 472-82.

Grube, G. M. A., trans. 1997. Plato: The Republic. Rev. C. D. C. Reeve. In Plato: Complete Works, ed. John M. Cooper and D. S. Hutchinson. Indianapolis.

Johansen, Thomas K. 1998. Truth, Lies and History in Plato's Timaeus-Critias. Histos 2: 192-215. 
Kamtekar, Rachana. 2006. Speaking with the Same Voice as Reason: Personification in Plato's Psychology. OSAP 31: 167-202.

Lear, Jonathan. 2006. Allegory and Myth in Plato's Republic. In Blackwell Guide to Plato's Republic, ed. Gerasimos Santas, 25-43. Oxford.

Mahon. John E. 2007. A Definition of Deceiving. International Journal of Applied Philosophy 21: 181-94.

Morgan, Kathryn. 2000. Mvth and Philosophv from the Presocratics to Plato. Cambridge.

Page, Carl. 1991. The Truth about Lies in Plato's Republic. Ancient Philosophv 11: 1-33.

Popper, Karl. 1966. The Open Society and Its Enemies ${ }^{5} .2$ vols. Princeton, N.J.

Reeve, C. D. C. 1988. Philosopher-Kings. Princeton, N.J.

Schofield, Malcom. 2007. The Noble Lie. In The Cambridge Companion to Plato's Republic, ed. G. R. F. Ferrari, 138-64, Cambridge. 2009. Fraternite, Inegalite, la Parole de Dieu: Plato's Authoritarian Myth of Political Legitimation. In Plato's Myths ed. Cataline Partenie, 101-15. Cambridge.

Simpson, David. 2007. Truth, Truthfulness and Philosophy in Plato and Nietzsche. British Journal for the Historv of Philosophy 15: 339-60.

Taylor, C. C. W. 1999. Plato's Totalitarianism. In Plato 2: Ethics, Politics, Religion, and the Soul, ed. Gail Fine, 280-96. Oxford.

Williams, David Lay. 2013. Plato's Noble Lie: From Kallipolis to Magnesia. History of Political Thought 34: 363-92.

Woolf, Raphael. 2009. Truth as a Value in Plato's Republic. Phronesis 54: 9-39. 